\title{
建築構造性能に関するアンケー A STUDY ON PERFORMANCE OF 卜調査による要求性能 BUILDING STRUCTURES BY QUESTIONNAIRES
}

\author{
藤谷秀雄 $-* 1$ 谷 明勲 $-* 2$ \\ 高橋郁夫——3 青木洋一— $* 4$ \\ キーワード \\ 建築構造, 要求性能, アンケート調查, ファジィ理論, 性能指向型の設計 \\ Keywords : \\ Building structure, Performance requirement, Questionnaires, Fuzzy theory, \\ Performance-based design
}

\section{Hideo FUJITANI — $* 1$ \\ Akinori TANI - *2 \\ IkUo TAKAHASHI $-* 3$ \\ Yoichi AOKI $-* 4$}

The following were observed as the results of questionnaire survey for building users and experts. They all have a clear idea and they want to suppress hazard severity to a small level. This is more evident for "hazard to human life" and "loss of property value" than for "function of building". If the fuzzy relation is used, the membership functions with respect to the structural damage level can be obtained from the performance requirement level. The performance requirement level is determined by users and owners for "hazard to human life" and "loss of property value". It thus becomes possible to convert the performance requirement level determined by users and owners to a structural damage level.
1.はじめに

建築構造においては、ユーザーの多様化かつ高度化している要求 を満足させるために、建築構造の保有寸る性能をできるだけ明確に 説明し、発注者との合意に基づいた性能とその水準を設定して設計 在行㧍う上する性能指向型の設計が重要視されつつある ${ }^{122}$ 。また具 体的に、耐震性能レバルをユーザーの要望を反映して設定しようと する試み年ある。

構造に起因する建築物の性能は、一般に「人命の保護」、「機能の 維持」、「財産の保全」といら3つの目的から議論されることが多い こ上から、筆者らは、こ机らの3つの目的に対して、一般の住民の 方々はそれぞれどのような性能を要求し、一方で建築の専閒家はど の上うな性能を付与すべきと考えているか子明らかにするため、ア ンケート調查を実施した。筆者らはアンケートによって、まず「身 にかかる危険度 (人命の保護に関わる状態)」、建物が受ける影響(機 能の維持に関わる状態)」、「不動産等の価値跴失（財産の保全に関わ る状態)」に関寸る意識を調查し、その後、「構造被害」上これらの 関保に対する意識を調查した。本報は、これらの調査結果に基づき、 ファジィシスラムの手法 4)5在用いて、「身にかかる危険度」および 「不動産等の価值培失」の観点から、許容される構造被害の程度、 言い換えれば、確保す心゙き性能の水準を示すことを試みた。

ファジィシステムの手法は、人間の思考や主観のように言語で表 現されるもの在数量化して取り扱える手法であり、本報のように要 求它把握寸る上いら目的のためには有効な手段と考学られる。

\section{2.アンケート調査の概要}

まず一般住民の方に対するアンケート調査は、兵庫県南部地震か ら 2 年半が経過した、1997 年の後半に実施された。建築専門家に対 するアンケート調查は、1998 年の春に実施された。それぞれの配 布・回収状況を、表 $1 ， 2$ 亿示寸。一般住民の方については電話帳 から、建築専門家については所属団体の名簿から、それぞれ無作為 抽出しアンケート票を直接郵送し、返信用封筒を同封して回収した。

\begin{tabular}{|c|c|c|c|c|c|c|c|}
\hline \multirow[b]{2}{*}{ 地域 } & \multirow[b]{2}{*}{ 都市名 } & \multicolumn{3}{|c|}{ 㳄 } & \multicolumn{3}{|c|}{ 次 } \\
\hline & & $\begin{array}{l}\text { 郵送 } \\
\text { 票数 a }\end{array}$ & $\begin{array}{l}\text { 回収 } \\
\text { 票数 b }\end{array}$ & $\begin{array}{c}\text { 回収率 } \\
\mathrm{b} / \mathrm{a} * 100\end{array}$ & $\begin{array}{c}\text { 郵送 } \\
\text { 票数 a }\end{array}$ & $\begin{array}{l}\text { 回収 } \\
\text { 票数 b }\end{array}$ & 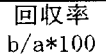 \\
\hline \multirow{6}{*}{ 首都圈 } & 都区部 & 1,200 & 411 & 34.2 & 411 & 248 & 60.3 \\
\hline & 横浜市 & 200 & 90 & 45.0 & 91 & 57 & 62.6 \\
\hline & 千葉市 & 200 & 72 & 36.0 & 71 & 45 & 63.4 \\
\hline & 大宮市 & 100) & 37 & 37.0 & 36 & 21 & $\overline{58.3}$ \\
\hline & (不明) & - & 3 & - & 1 & 1 & 100.0 \\
\hline & 合 計 & 1,700 & 613 & 36.1 & 610 & 372 & 61.0 \\
\hline \multirow{3}{*}{ 陬神圈 } & 大阪市 & 350 & 95 & 27.1 & 94 & 56 & 59.6 \\
\hline & 神户市 & 350 & 155 & 44.3 & 153 & 97 & 63.4 \\
\hline & 合 計 & 700 & 250 & 35.7 & 247 & 153 & 61.9 \\
\hline \multicolumn{2}{|c|}{ 仙台市 } & 300 & 107 & 35.7 & 108 & 70 & 64.8 \\
\hline \multicolumn{2}{|c|}{ 福 岡 市 } & 300 & 101 & 33.7 & 101 & 63 & 62.4 \\
\hline 合 & 訪 & 3,000 & 1,071 & 35.7 & 1,066 & 658 & 61.7 \\
\hline
\end{tabular}

表 2 建築専阴家へのアンケート票の配布・回収状況

\begin{tabular}{|c|c|c|c|}
\hline 団体名 & $\begin{array}{c}\text { 郵送票数 } \\
\text { a }\end{array}$ & $\begin{array}{c}\text { 回収票数 } \\
\mathrm{b}\end{array}$ & $\begin{array}{l}\text { 回収率 } \\
\mathrm{b} / \mathrm{a} * 100\end{array}$ \\
\hline $\begin{array}{l}\text { (社) 日本建築構造技術者協会 } \\
\text { (JSCA) }\end{array}$ & 200 & 100 & 50.0 \\
\hline (社) 建築設備技術者協会（設備） & 100 & 42 & 42.0 \\
\hline (社)日本建築家協会 (JIA) & 200 & 67 & 33.5 \\
\hline (社) 日本建築士会連合会 (JFABEA) & 200 & 67 & 33.5 \\
\hline 合計 & 700 & 276 & 39.4 \\
\hline
\end{tabular}

*1 Department of Structural Engineering, Building Research Institute, Dr. Eng.

*2 Assoc. Prof., Graduate School of Science and Technology, Kobe University, Dr. Eng.

*3 Izumi Research Institute, Shimizu Corporation, Dr. Eng.

*4 Architectural Engineering Department, Tokyu Construction Co., Ltd 


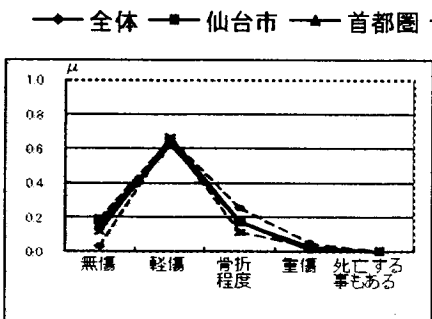

(a)やむを得ない状態

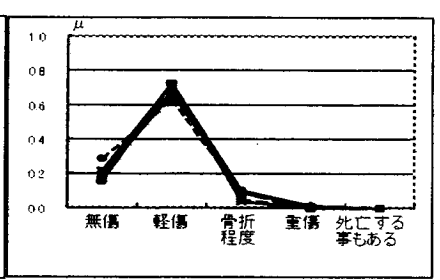

(b)本来あるべき状態
図 1 大地震時に身にかかる危険度に対する意識（一般住民）

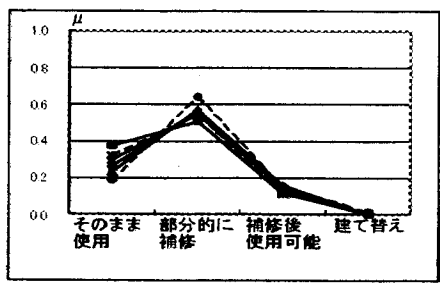

(a)やむを得ない状態

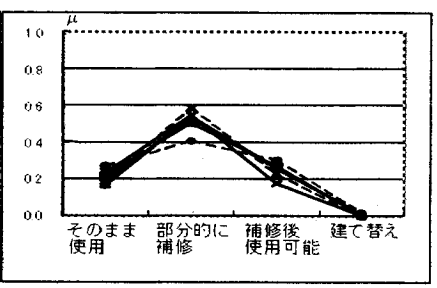

(b)本来あるべき状態
图 2 大地震時の建物への影響に対する意識（一般住民）

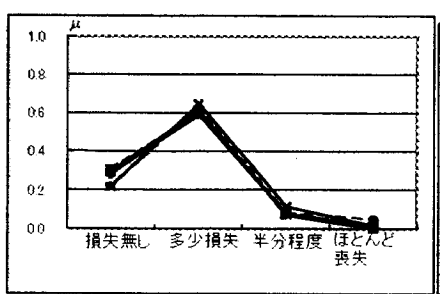

(a)やむを得ない状態

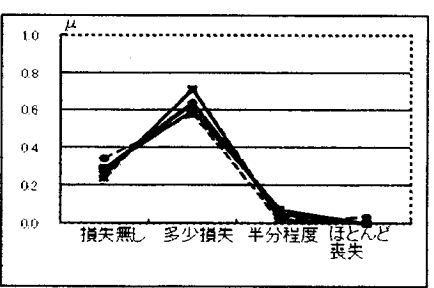

(b)本来ある心゙き状態
図3大地震時の財産の培失に対する意識（一般住民）

3．やむを得ない被害と本来あるべき状態

大地震に遭遇した際、起こりらる被害として、「身にかかる危険の 度合い、「新筑の建物が受ける影響の度合い、「不動産や財産の㖪 失の度合いの 3 点について、そ扎ぞれ「やむを得ない状態」と「本 来ある心゙き状態」について調查した。具体的には、「身にかかる危険 の度合い」に関しては、7つの選択肢(無傷, 軽いケガ, 骨折程度の ケガ，重傷，場合によっては死亡，その他，わからないを、「新築 の建物が受ける影響の度合いにに関しては、6つの選択肢(そのまま 住为続けられる，部分的に補俊が必要，補修すれば住める，建て替 えもやをを得ない，その他，わからないを、「不動産や財産の㕹失 の度合いに関しては、6つの選択肢（価值が失われてはならない， 多少失わ机てもやむ在得ない，半分程度失わ机てもやむを得ない， ほとんど失われてもやむ得ない，その他，わからない設定し、 それぞれ「やむを得ない状態」と「本来ある心゙き状態」を選択する 形式で質問した。なお想定する建築物は、一般住民に対しては「新 築の住宅」、建築専門家に対しては「新築の建物」とした。

一般住民に対する集計結果を図 $1 \sim 3$ に、建築専門家に対する集 計結果を図 $4 \sim 6$ に示寸。ここでは、その他、わからないの回答は 集計から除いた。な拉、評価の割合は、各設問の各選択肢の回答者 数を全回答者数で除して求め、言語表現された被害程度に対するつ アジィ理論 ${ }^{6)}$ の㷌属度関数の形式で表現した。すなわち、各選択肢 が選択された割合(評価)が、その選択肢に対する帰属度 $\mu$ となる。 一般住民の場合、身にかかる危険度に関しては、やむを得ない状態

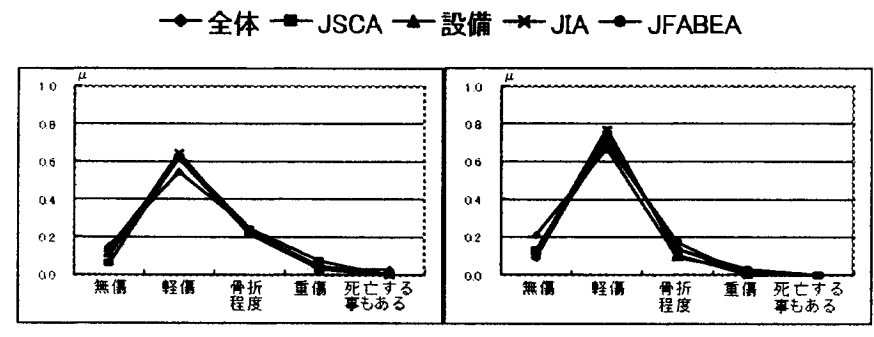

(a)やむを得ない状態

(b)本来あるべき状態

図4大地震時に身にかかる危険度に対寸る意識（建築専門家）

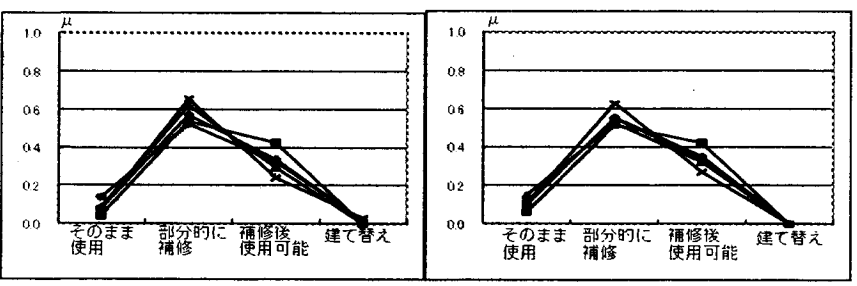

(a)やむを得ない状態

(b)本来あるべき状態

図 5 大地震時の建物への影響に対する意識（建築専門家）

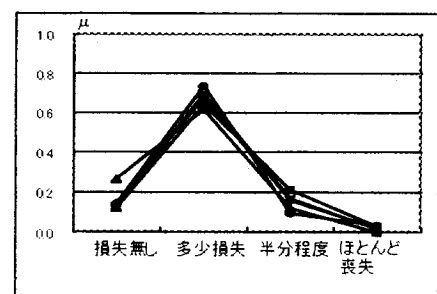

(a)やむを得ない状態

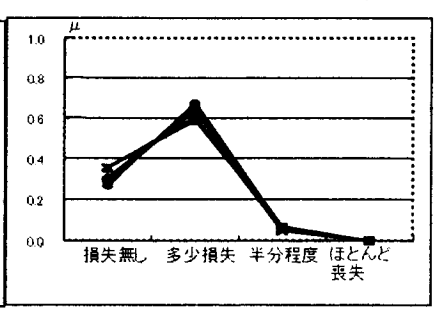

(b)本来あるべき状態
図 6 大地震時の財産の喪失に対する意識（建築専門家）

と本来あるぶき状態で評価の定性的傾向に大きな差は見られないが、 本来あるべき状態の評価では、やむを得ない状態の評価と比べて、 若干、より危険度が小さいことが高く評価されている（図 1)。

建物が受ける影響の度合い（図 2）および不動産・家財の雯失度 （図 3)に関しても、やむを得ない状態と本来あるべき状態ともに、 評価の定性的傾向に大きな差は見られないが、やむを得ない状態の 評価の方が、若干、より被害が小さいこ上が高く評価されている。

建築専門家の場合でも、一般住民の結果上ほぼ同様の傾向（図 4 〜6) であるが、新筑の建物が受ける影響の度合い（図 5) につい ては、やむを得ない場合、本来あるべき状態共に、「補修後使用可」 の評価に関して所属団体による若千の差が見られ、構造技術者が多 く老占める(社) 日本建築構造技術者協会 (JSCA) の結果では、「補修後 使用可」に対する帰属度が他の団体の結果に比べて大きくなり、構 造技術者が他の建築専門家に比心゙て、補修の意義をより重要視する 傾向が見られる。

一般住民、建築専門家の評価の結果を比較すると、両者とも身に かかる危険度、不動産・家財の軷失度に対寸る考え方の方が、新筑 の建物（住宅）の受ける影響に対する考え方に比べて、最大の評価 值(帰属度)がより大きく、また分布の広がりが小さい形状となって いる。このことから、建物への影響度（機能の維持）に比べて、身 にかかる危険度 (人命の保護) および不動産・家財の喪失度（財産 の保全）に対して、より明瞭な意識を有していることがわかる。 


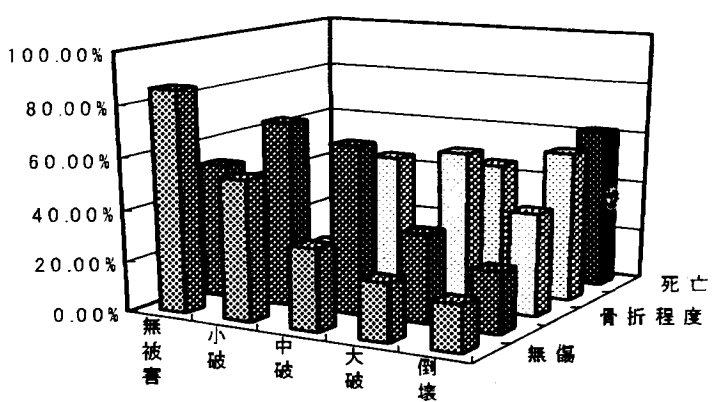

图7構造被害と身にかかる危険度（一般住民）

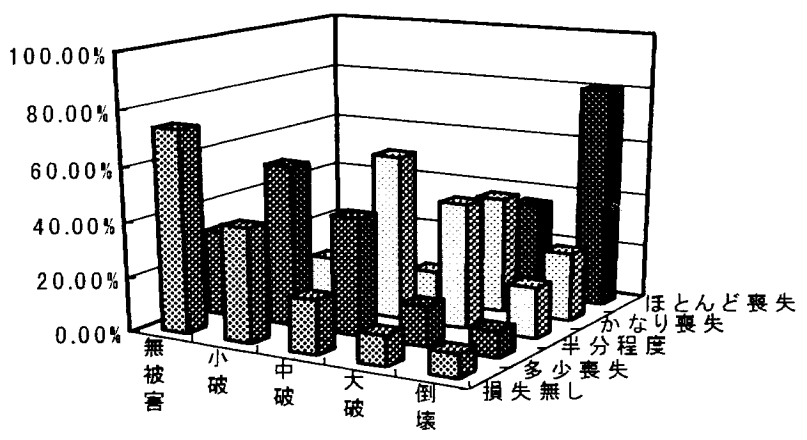

図8 構造被害と財産等の価値の喪失度（一般住民）

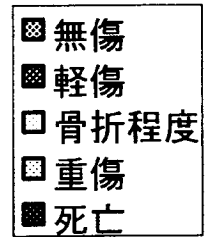

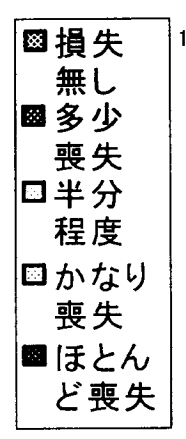

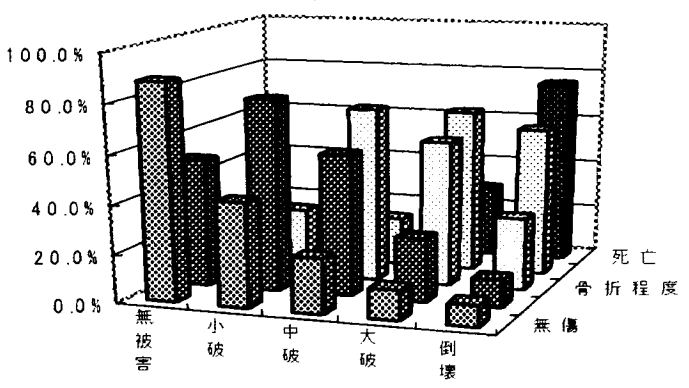

图9構造被害と身にかかる危険度（建築専門家）

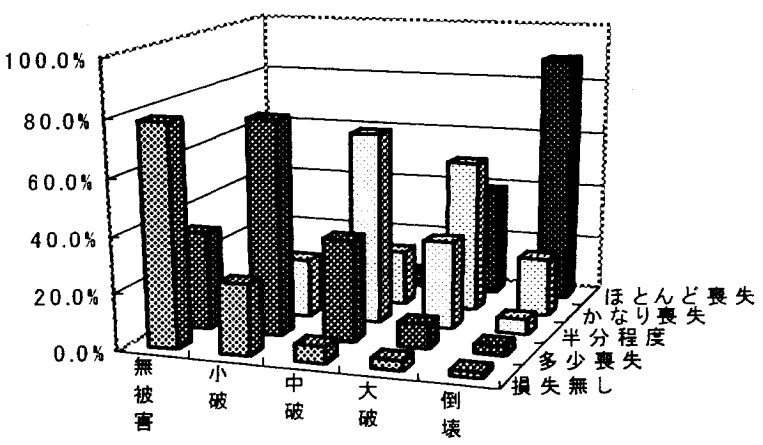

図 10 構造被害と財産等の価値の喪失度（建築専門家）

\section{4. 建物の構造被害と人命の危険度および財産価值の関係}

建物の構造被害之人命に対寸る危険度や財産価值の喪失度は、そ れぞれ単独に評価されるむのではなく、何らかの相関を有して評価 されるものと考えられる。そこで、構造被害を条件上した場合の人 命に対寸る危険度、及び不動産・家財の価值の喪失度に関するアン ケ一トを実施した。具体的には、構造被害として5段階（無被害· 軽微，小破、中破、大破、倒壊〉在設定し、それぞれの構造被害が 生じた場合の人命の危険度上して5 段階 (無傷, 軽傷, 骨折程度の ケガ, 重傷, 場合によっては死亡)、財産的価値の喪失度上して5段

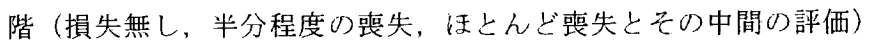
を設定し、それぞれの構造被害に対して生じると考えられる範囲を 回答寸る形式（単一の回答も可）とした。一般住民の集計結果在み る上、人命の危険度（図７）に括いては、構造被害の程度に対して 選択の割合高い選択肢は以下のようになっている。

$\begin{array}{ll}\text { (構造被害) 無被害・軽微 } & \rightarrow \text { 無傷 (人命の危険度) } \\ \text { 小破 } & \rightarrow \text { 無傷〜軽傷 } \\ \text { 中破 } & \rightarrow \text { 軽傷〜骨折程度のケガ } \\ \text { 大破 } & \rightarrow \text { 骨折程度のケガ〜重傷 } \\ \text { 倒懐 } & \rightarrow \text { 重傷〜死亡 }\end{array}$

寸なわち、構造被害が大きくなるにしたがって人命の危険度も大 きくなる評価となっているが、評価が分散寸る傾向が見られる。ま た、財産的価值の喪失の場合（図 8) も同様に、構造的被害が大さ くなるに伴って財産的損失む大きくなる評価上なっており、切妻状 の分布形状となっている。

建築関係者の集計結果でも、人命の危除度 (図9)、財産的価值 (図 10）上もに、多少の数值的なバラッキは見られるが、定性的傾向に 関しては一般住民の場合と同様である。

\section{5.アンケート結果から求めた構造被害}

このアンケートで実施した質問は、図 11 に示すようなファジィシ ステム 4)で表現することができる。また、フォジィシステムを用い た建築構造物の耐震安全性の工学的、社会的評価に関卞万研究も行 われ、その有效性が検討されている5）。また、ここで得られたアン ケート結果は、これらのファジィシステムにおけるファジィ関係 $\left(\mu_{\mathrm{R} 1}(\mathrm{x}, \mathrm{y}) ， \mu_{\mathrm{R} 2}(\mathrm{x}, \mathrm{z})\right)$ を与えるもりと考えることができる。

今回実施したアンケートでは、3章で示した、身にかかる危険度、 新築の建物の不動産価値や家財の価値の垔失度に関して、やむを得 ない状態と本来ある心゙き状態に対する設問を設定している。これら の結果を、図 11(a)、(b)に示寸2つのファジィ関倸の入力として設 定寸れば、人命の危険度、財産的価値の喪失それぞれの評価から、 以下の式を用いて構造被害の帰属度関数を $\mu_{\mathrm{A}}(\mathrm{x})$ 求めることが できる。

$$
\begin{aligned}
& \mu_{A}(x)=\max _{y \in Y}\left\{\mu_{B}(y) \wedge \mu_{R 1}(x, y)\right\} \\
& \mu_{A}(x)=\max _{z \in Z}\left\{\mu_{C}(z) \wedge \mu_{R 2}(x, z)\right\}
\end{aligned}
$$

ここで、 $\mathrm{x} ， \mathrm{y} ， \mathrm{z}$ は構造被害、身にかかる危険度、財産的価值それ ぞれの言語表現された評価に対灾し、X，Y，Zはそれぞれの台集合 全体を表している。また、式中へは、両側の值の小さい方の值をと

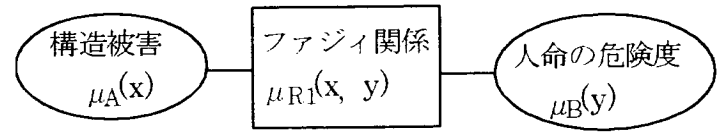

(a)構造被害之人命の危険度

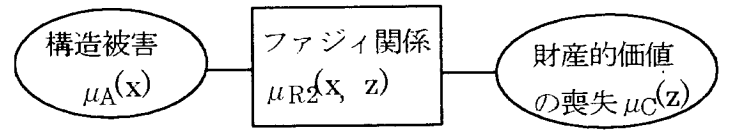

(b)構造被害上財産的価値の掍失

図 11 構造被害上人命あるいは財産の被害上の関係 


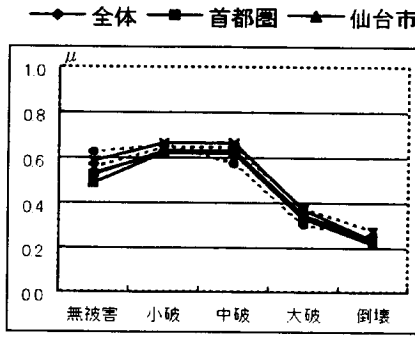

(a)やむを得ない状態

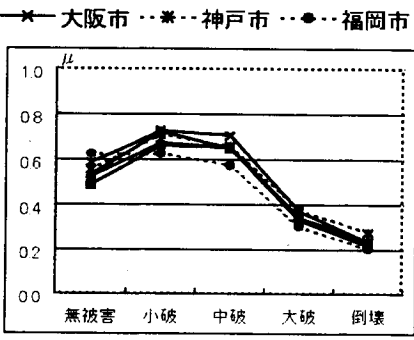

(b)本来あるべき状態
図 12 身にかかる危険度の意識から求めた構造被害（一般住民）

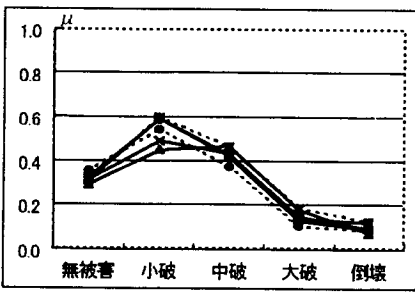

(a)やむを得ない状態

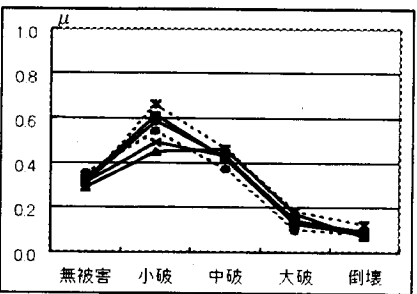

(b)本来あるべき状態
図 13 財産の喪失の意識から求めた構造被害（一般住民）

る $\min$ 演算を表す。また、総合的な構造被害に対する帰属度関数は、 式(1)，(2) から得られる帰属度関数をファジィ最大化決定 ${ }^{7)}$ 寸るこ とにより求めることができる。

一般住民の場合、身にかかる危険度に関寸る回答から求めた構造 被害に関する帰属度関数（図 12）は、やむを得ない状態では、小破 から中破に対寸る帰属度の值が高くなっているが、無被害・軽微の 場合上の差は小さく、分布に明瞭なピークは見られない。本来ある べき状態でも、小破から中破に対する㷌属度の值が高くなっており、 無被害・軽微の場合との差はやむを得ない場合の結果よりも若干大 きい。不動産・家財の峦失度に関する回答から求めた構造被害に関 する㷌属度関数（図 13）は、やむを得ない状態と本来あるべき状態 で定性的傾向に大きな差は見られない。この場合、身にかかる危険 度り場合よりもピークが明瞭に見られ、一般住民としては、身にか かる危険度よりも不動産・家財の価值の喪失に対寸る意識の方が明 瞭であることがわかる。

建築専門家の場合、身にかかる危険度に関寸る回答から求めた構 造被害に関寸る帰属度関数（図 14）は、やむを得ない状態では、小 破から中破に対する帰属度の值が高くなっているが、無被害・軽微 の場合との差は小さく、分布に明瞭なピークは見られない。本来あ るべき状態では、小破の被害に対してピークを有する分布となって いる。これより、建築専門家は身にかかる危険度と構造被害に関し て、一般住民の場合より、明瞭な意識を有しているこ上がわかる。 また、（社）日本建築構造技術者協会（JSCA）の場合、他の団体に比 べて大きな被害(中破，大破)に対する帰属度の值が大きくなってい る。不動産・家財の培失度に関する回答から求めた構造被害に関す る㷌属度関数（図 15）は、や搌得ない状態々本来あるべき状態で 定性的傾向に大きな差は見られない。この場合、構造被害としては 小破にピーク有する分布上なり、身にかかる危険度の場合よりも ピークが明瞭に見られ、建築専門家上しても、一般住民の場合と同 様に、身にかかる危険度よりも不動産・家財の価值の喪失に対する 意識の方が明瞭であるこ上がわかる。

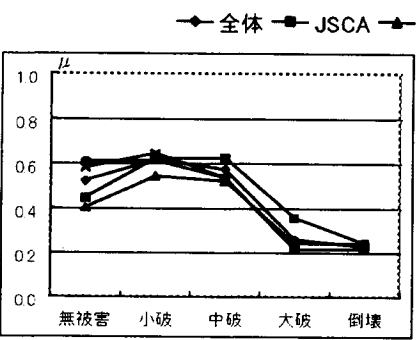

(a)やむを得ない状態

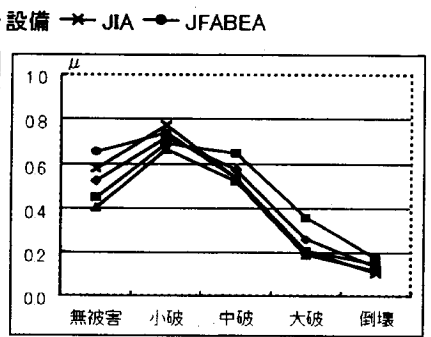

(b)本来あるべき状態
図 14 身にかかる危険度の意識から求めた構造被害(建築専門家)

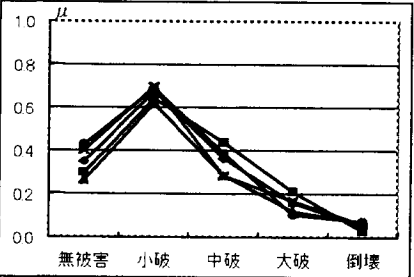

(a)やむを得ない状態

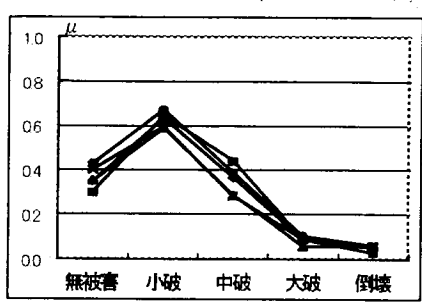

(b)本来あるべき状態
図 15 財産の喪失の意識から求めた構造被害（建築専門家）

\section{6. まとめ}

アンケート調查の結果、一般住民、建築専門家ともに、身にかか る危険度, 不動産・家財の喪失度に対寸る考え方の方が、新築の建 物（住宅）の受ける影響に対する考え方に比心゙て、より明瞭な意識 を有していることが明らかとなった。

今回のアンケートで得られたファジィ関倸を用いることによって、 一般住民が設定した身にかかる危険度や財産的価値の喪失に対する 要求水準から、構造被害の程度に対寸る帰属度関数を求めることが ぐきた。これにより、一般住民が設定した要求水準を構造被害のレ ベルに変換することが可能となり、性能指向型の設計において、種々 の応用が期待される。

このアンケート調查は、建設省（現、国土交通省）総合技術開発 プロジェクト「新建築構造体系の開発（総合委員会委員長：岡田恒 男 芝浦工業大学教授)」の目標水準分科会 (主查 : 青木義次 東京工 業大学教授)、性能水準WG、要求性能調査 SWGによって、平成 9 年度に行われたものである。関倸各位に、心から感謝申し上げます。 最後に、アンケートにご回答いただいた方々と、調查にご協力いた だいた関係各団体に、心から感謝申し上げます。

\section{参考文献}

1)（社）建築研究振與協会編：建筑構造に㧍ける性能指向型の設計，技報堂出 版, 2000.7 .

2)沼田竜一, 石川孝重, 平田京子：エーザーの要望を踏まえた性能設計り構 築に関する研究, 日本建築学会大会学術講演梗概集 B-1, 2000. 9, pp. 59-62.

3) 平田京子、石川孝重：ユーザーの要望を反映した耐震性能レベルの確率的 設定手法 0 提案, 構造工学論文集Vol. 47B, 2001.3，pp. 637-645

4）河村廣，ヤヨ，J.T.P.：条件付きファジィ集合に基づくファジィシステム 引構造工学入の応用に関する研究，構诰工学論文集，Vol. 36B，1990.3， pp. $51-56$.

5) 中島賢二，河村廣，谷明勲、田崎宗邦：アンケートレファジィシスデムを 㐫用した建物の耐震安全性の工学的並びに社会的評価に関する研究，第 5 回ファジィ建筑土木応用シンポジウム講演論文集, 1998.3， pp. 113-120.

6) Zadeh, L. A. : Fuzzy Sets, Information and Control, 8. pp. 338-353, 1965.

7) Bel Iman, R. E. and Zadeh, L. A., Decision-Making in a Fuzzy Environment, Management Sciences, Vol.17, No. 4, B-141-B-164, 1970.

[2001年 4 月20日原稿受理２001年 7 月27日採用決定］ 